\title{
KINERJA KAMBING BLIGON YANG DIPELIHARA PETERNAK DI DESA GIRI SEKAR, PANGGANG, GUNUNGKIDUL
}

\author{
PERFORMANCES OF BLIGON GOATS KEPT BY FARMERS AT GIRI SEKAR VILLAGE, \\ PANGGANG, GUNUNGKIDUL
}

\author{
Gatot Murdjito*, I Gede Suparta Budisatria, Panjono, Nono Ngadiyono, dan Endang Baliarti \\ Fakultas Peternakan, Universitas Gadjah Mada, Jl. Fauna No. 3, Bulaksumur, Yogyakarta, 55281
}

\section{INTISARI}

Penelitian dilaksanakan dengan tujuan untuk mengevaluasi kinerja kambing Bligon yang dipelihara oleh peternak di Desa Giri Sekar, Kecamatan Panggang, Gunungkidul, sebagai dasar untuk pelaksanaan program village breeding centre. Penelitian berlangsung selama tiga bulan, dimulai pada bulan Oktober sampai dengan Desember 2010 , di kelompok peternak kambing Bligon Purwo Manunggal yang berlokasi di Dusun Jerukan, Desa Giri Sekar, Kecamatan Panggang, Kabupaten Gunungkidul, Daerah Istimewa Yogyakarta. Materi penelitian adalah 20 peternak pemelihara sebagai responden dan kambing Bligon pada berbagai tingkatan umur, baik cempe, muda, induk maupun pejantan. Daftar pertanyaan digunakan untuk melakukan wawancara terhadap peternak. Metode penelitian yang digunakan adalah dengan wawancara, pengamatan dan pengukuran langsung di lapangan yang meliputi pengambilan data kinerja induk dan penimbangan bobot badan. Data yang diambil adalah profil peternak dan manajemen ternak, service per conception, litter size dan bobot badan. Data yang terkumpul dan bersifat kualitatif dianalisis secara deskriptif dan ditampilkan dalam persentase, sedangkan data yang bersifat kuantitatif dianalisis statistik dengan menggunakan Independent Sample T-test. Hasil penelitian menunjukkan bahwa sebanyak 37,9\% peternak menyatakan bahwa tujuan beternak adalah sebagai sumber pendapatan, sedangkan 34,5\% adalah untuk tabungan dan $27,6 \%$ bertujuan untuk memproduksi pupuk. Rerata jumlah kepemilikan ternak kambing sebanyak 4 ekor dengan kisaran 1-7 ekor. Rerata service per conception (S/C), lama bunting, litter size, post partum estrus, post partum mating, dan interval kelahiran induk kambing Bligon berturut-turut adalah 1,23; 5,5 bulan; 1,74 ekor; 63,2 hari; 95 hari dan 8,53 bulan. Pertambahan bobot badan harian $(\mathrm{PBBH})$ cempe, muda dan dewasa pada kambing Bligon jantan berturut-turut adalah 0,15; 0,29 dan 0,27 kg/ekor/hari, sedangkan pada betina adalah 0,16; 0,26 dan 0,15 kg/ekor/hari. Disimpulkan bahwa kinerja kambing Bligon adalah baik, ditinjau dari periode lama bunting, litter size, post partum estrus, post partum mating, interval kelahiran dan pertambahan bobot badan harian.

(Kata kunci: Kinerja, Kambing Bligon, Gunungkidul)

ABSTRACT

This study was conducted to evaluate performances of Bligon goats kept by farmers at Giri Sekar village, Panggang sub-district, Gunungkidul as basic information for establising the village breeding centre program. The research was conducted for three months, starting from October to December 2010, located at Purwo Manunggal farmers' group, Jerukan, Giri Sekar village, Panggang, Gunungkidul, Yogyakarta. Twenty farmers were involved during the study to be interviewed, while their goats were measured regularly. The parameter of goat meausred in this research were pre weaning, weaning, does and buck. Interviewing the farmers was done using questionnaire. Interview, direct measurement were applied to collect all required informations. The data consisted of farmer's background, possesion of goats and land, goats' daily management, service per conception, litter size, post partum estrus, post partum mating, kidding intervals, and average daily gain. Qualitative data were analysed descriptively and presented as percentage, while quantitative data were analysed using Independent Sample T-test, presented as mean and its standard error. The results showed that majority of the farmers (37.9\%) kept goat as main sources of income, while others were to saving (34.5\%) and produce manure (27.6\%). On average, the numbers of goat owned by the farmers was four heads, ranging from 1 to 7 heads. The average of service per conception $(S / C)$, gestation period, litter size, post partum estrus, post partum mating and kidding intervals of Bligon were 1.23; 5.5 months; 1.74 head; 63.2 days; 95 days and 8.53 months, respectively. The average daily gain of male kid, young and adult Bligon goats were 0.15; 0.29

\footnotetext{
* Korespondensi (corresponding author):

Telp. +62 811266059

E-mail: gatot-murdjito@yahoo.com
} 
dan $0.27 \mathrm{~kg} / \mathrm{head} /$ day, while for female Bligon gotas were $0.16 ; 0.26$ and $0.15 \mathrm{~kg} / \mathrm{head} /$ day, respectively. It is concluded that performances of Bligon goats was high in terms of litter size, post partum estrus, post partum mating, gestation period, kidding intervals and average daily gain.

(Keywords: Performance, Bligon goats, Gunungkidul)

\section{Pendahuluan}

Indonesia memiliki sumber daya genetik ternak yang beraneka ragam dan merupakan aset besar dalam usaha pengembangan ternak. Berbagai rumpun ternak lokal spesifik lokasi, baik yang sudah dikenal umum maupun yang belum dapat ditemukan di setiap propinsi dengan jumlah dan potensi yang belum diketahui. Rumpun tersebut mempunyai keunggulan komparatif dibanding ternak impor, antara lain daya adaptasi yang baik terhadap lingkungan tropis dengan sifat reproduksi yang baik sebagai akibat seleksi alam yang alami.

Diantara berbagai jenis ternak lokal, kambing merupakan ternak yang banyak dipelihara. Ternak kambing merupakan jenis ternak yang cukup digemari masyarakat, namun skala usahanya masih bersifat usaha kecil dengan sistem pemeliharaan dan perkembangbiakannya masih secara tradisional. Pemeliharaan kambing secara lepas (tradisional) umumnya sebagai usaha sambilan bagi peternak, meskipun ada juga yang menjadikannya sebagai mata pencaharian pokok.

Jenis kambing yang saat ini banyak mendapat perhatian adalah kambing Bligon. Kambing Bligon menurut Hardjosubroto dan Astuti (1993) adalah sebutan untuk kambing silangan dari kambing lokal (kambing Kacang) dan kambing Peranakan Etawah (PE). Menurut Djajanegara dan Misniwaty (2004) cit. Fitriani (2008), kambing Bligon mempunyai komposisi darah kambing Kacang lebih dari 50\% dan banyak tersebar di Pantai Utara Jawa dan Yogyakarta.

Keunggulan ternak lokal sebagai plasma nutfah nasional belum banyak terungkap, sedangkan usaha pelestarian dan pemanfaatannya baru sebatas wacana, disisi lain erosi dan pencemaran plasma nutfah terus terjadi, sehingga dikhawatirkan akan mengalami kepunahan (Astuti et al., 2007). Selain itu, karena perhatian dari pihak-pihak terkait yang kurang dari segi pembinaan, telah mengakibatkan produktivitas kambing Bligon menjadi menurun, minat peternak untuk memelihara kambing Bligon telah bergeser pada kambing dengan ukuran tubuh yang lebih besar serta populasi kambing Bligon yang cenderung tidak berkembang. Di tingkat peternak, permasalahan yang dihadapi dalam rangka pengembangan ternak kambing Bligon mencakup manajemen pemeliharaan dan kontinyuitas usaha. Dalam bidang pemasaran, seringkali peternak tidak dapat memenuhi permintaan pasar secara kontinyu dan standar yang ditetapkan, sehingga harga jual ternak rendah. Hal ini berakibat pada rendahnya tingkat pendapatan peternak dari usaha ternak.

Salah satu cara yang dapat dilakukan dalam rangka pemurnian dan peningkatan mutu genetik serta produktivitas ternak adalah melalui program village breeding centre (VBC), karena dalam VBC kegiatan yang dilakukan meliputi seleksi dan introduksi pejantan unggul untuk mencegah inbreeding dan meningkatkan produktivitas. Langkah awal dalam rangka pelaksanaan VBC adalah melakukan inventarisasi tentang populasi dasar dan kinerja ternak, yang akan menjadi data dasar dan pedoman dalam rangka peningkatan produktivitas. Produktivitas yang dimaksud mencakup kinerja produksi dan reproduksi.

Oleh karena itu, maka perlu dilakukan penelitian awal tentang kondisi kinerja kambing Bligon yang dipelihara oleh peternak sebagai landasan pembentukan VBC, sehingga pada masa mendatang, produktivitas dan mutu genetik ternak kambing Bligon dapat ditingkatkan.

\section{Materi dan Metode}

\section{Waktu dan lokasi penelitian}

Penelitian berlangsung selama tiga bulan, dimulai pada bulan Oktober sampai dengan Desember 2010. Penelitian dilakukan di kelompok peternak kambing Bligon Purwo Manunggal yang berlokasi di Dusun Jerukan, Desa Giri Sekar, Kecamatan Panggang, Kabupaten Gunungkidul, Daerah Istimewa Yogyakarta. Materi penelitian terdiri dari ternak kambing Bligon pada berbagai tingkatan umur, baik induk, cempe, pejantan maupun kambing muda yang dipelihara oleh peternak. Selain ternak kambing, penelitian ini juga melibatkan 20 orang peternak pemelihara sebagai responden. Untuk mengetahui manajemen pemeliharaan ternak, selain pengamatan langsung di lapangan, juga dilakukan wawancara dengan peternak dengan bantuan kuesioner yang telah disiapkan sebelumnya.

\section{Metode penelitian}

Penelitian ini merupakan studi kasus kinerja kambing Bligon pada kelompok peternak Purwo Manunggal, Dusun Jerukan, Desa Giri Sekar, Kecamatan Panggang, Kabupaten Gunungkidul, 
Daerah Istimewa Yogyakarta. Metode penelitian yang digunakan adalah wawancara, pengamatan dan pengukuran langsung di lapangan yang meliputi pengambilan data kinerja induk dan pertumbuhan ternak.

Data profil peternak dan manajemen pemeliharaan terdiri atas umur peternak, mata pencaharian, pendidikan, jumlah keluarga, komposisi dan kepemilikan ternak, tujuan beternak, tujuan produksi serta tipe kandang yang digunakan. Data kinerja meliputi service per conception, litter size, post partum estrus, post partum mating, interval kelahiran, dan bobot badan.

Wawancara dilakukan dengan bantuan kuesioner untuk memperoleh data tentang profil peternak dan manajemen pemeliharaan. Wawancara dilakukan dengan mendatangi peternak dan dilakukan secara individual. Data kinerja induk diamati dengan menggunakan kartu catatan ternak. Kartu tersebut dibagikan kepada peternak yang selanjutnya dengan bimbingan peneliti, peternak akan mengisi kartu tersebut pada saat ternaknya kawin, tanggal lahir, estrus kembali setelah beranak serta kawain pertama setelah beranak. Sistem perkawinan yang diterapkan oleh peternak adalah kawin alam, karena penerapan inseminasi buatan belum populer di kalangan peternak kambing di lokasi penelitian. Cara mengawinkan ternak adalah dengan membawa betina yang menunjukkan birahi pada peternak yang mempunyai pejantan, karena terbatasnya jumlah pejantan yang ada di lokasi penelitian. Apabila selama satu siklus estrus ternak menunjukkan tandatanda birahi kembali, maka peternak akan mengulang perkawinan induk kambing dengan cara membawa kembali induk tersebut ke peternak yang mempunyai pejantan.

Data service per conception diperoleh dengan mengamati jumlah perkawinan sampai terjadi kebuntingan yang tercatat dalam kartu recording, kemudian direrata. Data litter size diperoleh dengan pengamatan terhadap jumlah anak seke-lahiran, kemudian hasil pengamatan dirata-rata. Data post partum estrus dan post partum mating di-peroleh dengan melakukan wawancara dan melihat kartu recording ternak yang ada di setiap peternak. Interval kelahiran ditentukan dengan cara melihat catatan yang ada di peternak tentang tanggal beranak induk kambing selama dua kali kelahiran berturut-turut, sehingga dapat ditentukan jarak antar kelahiran.

Penimbangan bobot badan ternak dilakukan setiap bulan sekali dengan menggunakan timbangan badan. Pertambahan bobot badan harian $(\mathrm{PBBH})$ kemudian dihitung dengan cara mengurangi bobot badan ternak pada akhir penelitian dengan bobot badan ternak awal penelitian, dibagi dengan lama hari pengamatan, dinyatakan dalam g/ekor/hari. Perhitungan PBBH dibedakan atas status ternak, yaitu cempe, muda, dan dewasa.

\section{Analisis data}

Data yang terkumpul dan bersifat kualitatif dianalisis secara deskriptif dan ditampilkan dalam persentase, sedangkan data yang bersifat kuantitatif dianalisis statistik dengan menggunakan Independent Sample T-test dan dihitung standard error.

\section{Hasil dan Pembahasan}

\section{Profil peternak}

Profil peternak di kelompok peternak kambing Bligon Purwo Manunggal yang berlokasi di Dusun Jerukan, Desa Giri Sekar, Kecamatan Panggang, Kabupaten Gunungkidul, Daerah Istimewa Yogyakarta, berdasarkan pengamatan di lapangan dan wawancara dengan peternak, tersaji pada Tabel 1.

Rerata umur peternak adalah 44,9 tahun, dengan umur termuda 22 tahun dan tertua adalah 65 tahun. Hal ini menunjukkan bahwa peternak masih berada dalam kisaran umur produktif, meskipun ada beberapa peternak yang sudah masuk kategori umur tidak produktif. Umur peternak akan sangat berpengaruh terhadap mobilitas peternak dalam memelihara ternaknya, semakin muda maka akan semakin gesit, sehingga diharapkan dengan umur muda dan produktif peternak akan mampu memelihara ternaknya dengan baik dan produktivitas ternak akan meningkat.

Sebagian besar peternak bermata pencaharian petani $(83,3 \%)$ sedangkan mata pencaharian pokok lainnya adalah buruh $(4,2 \%)$ dan wiraswasta $(12,5 \%)$. Hasil wawancara menunjukkan bahwa tidak satupun responden yang menyatakan bahwa mata pencaharian pokoknya adalah beternak. Walaupun demikian, peternak nampaknya juga sudah menganggap bahwa beternak kambing merupakan salah satu sumber pendapatan selain sebagai tabungan. Sebanyak $37,9 \%$ peternak menyatakan bahwa tujuan beternak adalah sebagai sumber pendapatan, sedangkan $34,5 \%$ adalah untuk tabungan dan $27,6 \%$ bertujuan untuk memproduksi pupuk, hal ini berbeda dengan hasil penelitian Budisatria (2006) yang mendapatkan bahwa ternak kambing belum layak digunakan sebagai mata pencaharian pokok dan masih dianggap sebagai usaha sampingan dan tabungan yang sewaktu-waktu bisa dijual apabila peternak membutuhkan uang mendadak. Perbedaan tersebut kemungkinan disebabkan karena kondisi daerah. Di Gunungkidul, khususnya di Giri Sekar merupakan daerah yang sangat kering dan dekat dengan hutan, sehingga 
Tabel 1. Profil peternak kambing Bligon (the profile of Bligon's farmers)

\begin{tabular}{|c|c|c|}
\hline \multirow[b]{2}{*}{ Parameter (parameters) } & \multicolumn{2}{|c|}{ Nilai (value) } \\
\hline & $\begin{array}{l}\text { Kisaran } \\
\text { (range) }\end{array}$ & $\begin{array}{c}\text { Rerata } \\
\text { (average) }\end{array}$ \\
\hline Jumlah peternak (orang) (numbers of farmers (person)) & \multicolumn{2}{|c|}{24} \\
\hline Umur peternak (tahun) (farmers age (year)) & $22-65$ & 44,90 \\
\hline \multicolumn{3}{|l|}{ Mata pencaharian (\%) (job (\%)) } \\
\hline Petani (farmers) & & 83,30 \\
\hline Buruh (hired labour) & & 4,20 \\
\hline Wiraswasta (bussiness) & & 12,50 \\
\hline Pengalaman beternak (tahun) (farmer's experiences (year)) & $2-40$ & 13,00 \\
\hline \multicolumn{3}{|l|}{ Pendidikan (\%): (education (\%)) } \\
\hline Tidak sekolah (illiteracy) & & 16,70 \\
\hline Tamat SD (elementary school) & & 37,50 \\
\hline Tamat SMP (junior high school) & & 29,30 \\
\hline Tamat SMA (senior high school) & & 12,50 \\
\hline Jumlah anggota keluarga (orang) (numbers of family member (person)) & $1-6$ & 3,90 \\
\hline \multicolumn{3}{|l|}{ Keterlibatan anggota keluarga (\%): (involvement of family members (\%)) } \\
\hline Ayah (father) & & 65,80 \\
\hline Ibu (mother) & & 28,90 \\
\hline Anak (children) & & 5,30 \\
\hline
\end{tabular}

beternak kambing merupakan sumber pendapatan utama bagi keluarga, hal ini didukung pula oleh tingginya mutasi ternak yang terjadi setiap bulan.

Ditinjau dari pengalaman beternak, peternak telah mempunyai pengalaman yang cukup matang dalam memelihara ternak karena rata-rata pengalaman beternak lebih dari 10 tahun, meskipun kisaran lama beternak sangat variatif yaitu 2-40 tahun. Pengalaman beternak akan berpengaruh terhadap kebiasaan-kebiasaan yang dilakukan yang berkaitan dengan manajemen ternak.

Mayoritas tingkat pendidikan terakhir peternak adalah SD (37,5\%), bahkan peternak yang tidak pernah mengenyam pendidikan formal juga masih tinggi $(16,7 \%)$, sedangkan yang berpendidikan SMP dan SMA berturut-turut sebesar 29,3\% dan $12,5 \%$. Hasil penelitian ini masih lebih baik dibandingkan dengan hasil penelitian Budisatria et al. (2009) yang mendapatkan bahwa mayoritas tingkat pendidikan terakhir peternak adalah SD (76,19\%), bahkan peternak yang tidak pernah mengenyam pendidikan formal juga masih tinggi $(14,29 \%)$. Tingkat pendidikan peternak merupakan salah satu faktor yang akan melancarkan program penyuluhan yang dilakukan oleh Dinas Peternakan setempat. Tingkat pendidikan yang relatif baik pada penelitian ini juga berpengaruh terhadap manajemen ternak. Di kelompok Purwo Manunggal, peternak juga telah melakukan pencatatan secara rutin $(72,7 \%)$, dan hanya $27,3 \%$ yang belum melaksanakan serta administrasi kelompok sudah sangat tertib.

Ciri peternakan tradisional adalah pelibatan tenaga kerja keluarga dalam mengurus ternak. Hasil penelitian menunjukkan bahwa walaupun jumlah anggota keluarga peternak cukup besar (3,9 orang) dengan kisaran 1-6 orang, akan tetapi keterlibatan anggota keluarga masih relatif kecil. Persentase keterlibatan dalam mengurus ternak kambing didominasi oleh ayah dan ibu, yaitu $65,8 \%$ dan $28,9 \%$, sedangkan keterlibatan anak sebesar 5,3\% atau dapat dikatakan bahwa mengurus ternak masih merupakan tanggungjawab kepala keluarga dan istrinya, sedangkan anak-anak tidak terlibat secara langsung. Budisatria et al. (2007) menyatakan bahwa jumlah anggota keluarga yang terlibat dalam mengurus ternak kambing adalah 2,0-2,6 orang. Hasil ini mengindikasikan bahwa peternak tidak ingin melibatkan anak-anaknya dalam mengurus ternak, selain itu, peternak tidak ingin anaknya menjadi peternak karena mereka menganggap bahwa ternak kambing tidak dapat digunakan sebagai sumber mata pencaharian pokok, seperti yang dinyatakan oleh Budisatria (2000).

Rerata jumlah kepemilikan ternak kambing yang dimiliki oleh kelompok ternak Purwo Manunggal sebanyak 4 ekor dengan kisaran 1-7 ekor, dari jumlah tersebut, $95,8 \%$ adalah milik sendiri sedangkan sisanya $4,2 \%$ adalah gaduhan (Tabel 2). Dari jumlah kepemilikan tersebut, struktur populasi terbesar adalah induk $(38,5 \%)$, diikuti oleh cempe betina $(22,0 \%)$, jantan dewasa $(16,0 \%)$, cempe jantan $(6,6 \%)$, dara $(6,6 \%)$ dan yang paling rendah adalah jantan muda $(5,0 \%)$. Hal ini dapat dipahami karena tujuan sistem pemeliharaan adalah bibit atau menghasilkan anakan (72,2\%), sehingga komposisi terbesar adalah induk dan cempe. 
Tabel 2. Kepemilikan ternak dan tujuan pemeliharaan (number of goats owned by the farmers and objectives of keeping goats)

\begin{tabular}{|c|c|c|}
\hline \multirow{2}{*}{ Parameter (parameters) } & \multicolumn{2}{|c|}{ Nilai (value) } \\
\hline & Kisaran (range) & Rerata (average) \\
\hline Kepemilikan ternak (ekor) (goats numbers (head)) & $1-7$ & 4,00 \\
\hline \multicolumn{3}{|l|}{ Komposisi kepemilikan ternak (\%): (population structure (\%)) } \\
\hline Cempe jantan (0-3 bulan) (male pre-weaning (0-3 months)) & & 11,00 \\
\hline Cempe betina ( $0-3$ bulan) (female pre-weaning ( $0-3$ months $)$ ) & & 22,00 \\
\hline Jantan muda (6-12 bulan) (young male (6-12 months)) & & 5,50 \\
\hline Dara (6-12 bulan) (young female (6-12 months)) & & 6,60 \\
\hline Induk (lebih dari 12 bulan) (doe (more than 12 months)) & & 38,50 \\
\hline Jantan dewasa (lebih dari 12 bulan) (buck (more than 12 months)) & & 16,50 \\
\hline \multicolumn{3}{|l|}{ Status kepemilikan ternak (\%): (ownership status of goats (\%)) } \\
\hline Milik sendiri (private) & & 95,80 \\
\hline Gaduhan (sharing) & & 4,20 \\
\hline Kepemilikan lahan hijauan $\left(\mathrm{m}^{2}\right)$ : (ownership of forages land $\left(\mathrm{m}^{2}\right)$ ) & $120-25.000$ & 11.097 \\
\hline Sendiri (ownself) & $120-5.000$ & 944,30 \\
\hline Sewa $($ rent $)$ & $20.000-25.000$ & 21.250 \\
\hline \multicolumn{3}{|l|}{ Tujuan beternak (\%): (objectives of goats keeping (\%)) } \\
\hline Pendapatan (cash income) & & 37,90 \\
\hline Tabungan (saving) & & 34,50 \\
\hline Pupuk (manure) & & 27,60 \\
\hline \multicolumn{3}{|l|}{ Tujuan produksi (production systems): } \\
\hline Penggemukan (feedlot) & & 27,80 \\
\hline Anakan (breeding) & & 72,20 \\
\hline \multicolumn{3}{|l|}{ Tipe kandang (\%): (housing types (\%)) } \\
\hline Panggung (slatted floor) & & 0 \\
\hline Tanah (ground floor) & & 100,00 \\
\hline \multicolumn{3}{|l|}{ Penempatan ternak (\%): (animal placement (\%)) } \\
\hline Koloni (colony) & & 91,70 \\
\hline Individu (individual) & & 8,30 \\
\hline
\end{tabular}

Hasil penelitian menunjukkan bahwa rerata luas kepemilikan lahan hijauan per peternak adalah $11.097 \mathrm{~m}^{2}$ walaupun variasi kepemilikan lahan sangat besar $\left(120-25.000 \mathrm{~m}^{2}\right)$. Luas lahan hijuan tersebut merupakan milik sendiri dengan rerata kepemilikan $944,3 \mathrm{~m}^{2}$ dan sewa $21.250 \mathrm{~m}^{2}$. Berdasarkan atas kepemilikan lahan hijauan, terlihat bahwa peternak telah mempersiapkan ketersediaan sumber pakan bagi ternak. Selain dari lahan hijauan, peternak juga memberikan berbagai tanaman liar yang tumbuh di sekitar hutan, tidak kurang dari 21 jenis tumbuhan liar sering digunakan sebagai pakan ternak, nama-nama tanaman liar (nama lokal) yang diberikan oleh peternak diantaranya adalah: midosari, asem madu, lilinan, bibisan, talokan, pingganan, sambang pantek, popohan, simbaran, cendana, adem ati, kakasan, sembukan, laban, ciplukan, bintaos, kukun, meniran, cukilan, gadel, kilayu, sigar jalak, cemloko, rempelas, sigunggu, dempul lelet, dan adal-adal. Tanaman-tanaman liar tersebut masih dalam tahap identifikasi, sehingga akan diketahui nama umum dan nama latin serta kandungan nutriennya.

Ditinjau dari tujuan memelihara ternak, terlihat bahwa peternak di kelompok ini sudah me- manfaatkan ternaknya sebagai sumber pendapatan utama bagi keluarga (37,9\%), sedangkan tujuan untuk tabungan dan menghasilkan pupuk berturutturut adalah $34,5 \%$ dan $27,6 \%$. Hasil ini berbeda dengan beberapa hasil penelitian terdahulu (Budisatria, 2006; Budisatria et al., 2009) yang menyatakan bahwa sebagian besar tujuan beternak untuk tabungan. Hal ini kemungkinan disebabkan karena peternak pada penelitian ini merupakan masyarakat yang tinggal di daerah kering dan berbatasan dengan hutan, sehingga beternak menjadi satu-satunya mata pencaharian. Pemeliharaan kambing dengan tujuan utama untuk menghasilkan pupuk kemungkinan disebabkan karena pupuk sangat dibutuhkan untuk memupuk lahan yang sangat kering dan tandus.

Mayoritas peternak mengaku bahwa tujuan produksi ternak kambing adalah menghasilkan anakan $(72,2 \%)$, sedangkan tujuan penggemukan cukup rendah $(27,8 \%)$, hal ini dapat dipahami karena pemeliharaan kambing untuk digemukkan membutuhkan pakan yang berkualitas baik dan biaya produksi untuk penggemukan tidak mampu diimbangi oleh kenaikan bobot badan harian yang tinggi. 
Seluruh peternak menggunakan kandang berlantai tanah untuk memelihara ternak kambing, hal ini sangat berbeda dengan hasil penelitian Aka (2008) yang mendapatkan bahwa tipe kandang panggung merupakan kandang yang paling banyak digunakan oleh peternak di Kabupaten Sleman. Ternak juga dipelihara dalam kandang koloni $(91,7 \%)$ dan hanya $8,2 \%$ peternak memelihara kambingnya dengan menggunakan kandang individu. Hal ini kemungkinan disebabkan karena penggunaan kandang panggung dan sistem individu membutuhkan biaya yang relatif besar. Selain itu, dengan menggunakan kandang berlantai tanah, maka sisa pakan akan langsung bercampur dengan kotoran, sehingga apabila terus menumpuk, maka akan diproduksi kompos dengan cukup banyak. Hal ini didukung oleh kenyataan bahwa hampir semua peternak tidak pernah melakukan pembersihan kandang secara rutin, kandang biasanya dibersihkan setiap 6 bulan sekali. Adanya sisa pakan yang dibiarkan menumpuk di kandang juga dimaksudkan sebagai alas kandang, sehingga kandang tetap kering meskipun berlantai tanah. Walaupun kandang tidak dibersihkan secara rutin, peternak menyatakan bahwa hal tersebut tidak berdampak pada kondisi kesehatan kambing dan dari catatan yang ada, tidak ada kasus kematian maupun ternak sakit yang diakibatkan oleh kondisi kandang yang jarang dibersihkan, hal ini kemungkinan karena alas kandang yang dijaga tetap kering.

\section{Kinerja reproduksi}

Hasil penelitian tentang kinerja reproduksi yang meliputi service per conception, lama bunting, litter size, post partum estrus, post partum mating dan interval kelahiran induk kambing Bligon di kelompok Purwo Manunggal, tersaji pada Tabel 3. Service per conception atau S/C (jumlah perkawinan per kebuntingan) merupakan faktor yang mempengaruhi efisiensi reproduksi, dan yang terbaik adalah satu kali (Kusnadi, 1980). Makin rendah nilai $\mathrm{S} / \mathrm{C}$, makin tinggi kesuburan ternak induk, sebaliknya makin tinggi nilai tersebut, makin rendah kesuburan ternak induk tersebut. Rerata service per conception (S/C) induk kambing Bligon yang dipelihara peternak pada penelitian ini adalah 1,23 kali, dengan kisaran 1-2 kali. Rustadi (2008), dalam penelitiannya di Klaten mendapatkan bahwa S/C pada induk kambing Bligon adalah 1,59. Dibandingkan dengan hasil penelitian terdahulu, maka nilai S/C pada penelitian ini lebih baik, hal ini kemungkinan disebabkan oleh sebagian besar sistem pemeliharaan ternak yang dilakukan oleh peternak adalah sistem koloni, sehingga apabila ada induk yang minta kawin, akan segera terdeteksi oleh jantan yang dikandangkan secara bersama-sama, sehingga S/C yang dihasilkan juga semakin rendah.

Lama bunting adalah waktu dari saat terjadinya fertilisasi sampai saat kelahiran normal (Hafez, 2000). Rerata lama bunting induk kambing Bligon yang dipelihara oleh peternak di kelompok Purwo Manunggal adalah 5,5 bulan dengan kisaran 5-6 bulan, angka ini menunjukkan bahwa lama bunting induk kambing Bligon pada penelitian ini cukup panjang. Loliwu (2002) melaporkan lama bunting kambing Kacang adalah sekitar lima bulan, sedangkan Astuti et al. (2007) menyatakan bahwa lama bunting kambing PE adalah 5-6 bulan. Lama bunting bervariasi tergantung dari spesies ternak, bahkan antar individu dalam spesies yang sama. Jaenudeen dan Hafez (1987) menyatakan bahwa lama bunting seekor ternak dipengaruhi oleh faktor genetik dan faktor lingkungan (internal dan eksternal).

Jumlah anak sekelahiran atau litter size yang dihasilkan oleh induk kambing Bligon dalam penelitian ini adalah 1,74 ekor dengan kisaran 1-2 ekor atau $73,81 \%$ induk beranak kembar 2, sedangkan 26,19\% induk beranak tunggal (Tabel 3). Litter size dalam penelitian ini umumnya termasuk kategori tinggi, terutama jika dibandingkan dengan litter size kambing Bligon hasil penelitian Rustadi (2008) yang mendapatkan litter size ternak kambing Bligon 1,47 ekor, dan Prayitno (2003) yang memperoleh nilai litter size kambing Bligon 1,40-1,45. Hasil penelitian ini hampir sama dengan hasil

Tabel 3. Kinerja reproduksi induk kambing Bligon (reproductive performances of Bligon does)

\begin{tabular}{lcc}
\hline \multicolumn{1}{c}{ Parameter (parameters) } & \multicolumn{2}{c}{ Nilai (value) } \\
\cline { 2 - 3 } & Kisaran (range) & Rerata (average) \\
\hline Service per conception (kali) (service per conception (time)) & $1,23 \pm 0,5$ \\
Lama bunting (bulan) (gestation period (month)) & $5,0-6,0$ & $5,5 \pm 1,3$ \\
Litter size (ekor) (litter size (head)) & $1-2$ & $1,74 \pm 0,45$ \\
Tipe kelahiran (birth types): & \\
Tunggal (\%) (single (\%)) & 36,19 \\
Kembar (\%) (twin (\%)) & 43,81 \\
Post partum estrus (hari) (post partum estrus (day)) & 65,120 & 730,56 \\
Post partum mating (hari) (post partum mating (day)) & $7-12$ & $95,0 \pm 45,5$ \\
Interval kelahiran (bulan) (kidding intervals (month)) & $8,53 \pm 1,93$ \\
\hline
\end{tabular}


penelitian Widi (2002) dan Sutimah (2003) yang mendapatkan litter size kambing Bligon berturutturut 1,81 dan 1,61-1,82 ekor. Tinggi rendahnya litter size antara lain dipengaruhi oleh faktor genetik, faktor umur induk, bobot badan induk dan tingkat nutrisi (Doloksaribu et al., 2005), lingkungan dan mikro klimat tempat ternak itu berada (Hardjosubroto, 1994), tingkat konsumsi pakan, pemberian pakan dengan tingkat nutrisi yang lebih tinggi pada saat menjelang ovulasi akan meningkatkan jumlah ovum yang diovulasikan (Inounu, 1996).

Post partum estrus merupakan faktor penting yang mempengaruhi efisiensi reproduksi pada kambing. Makin pendek selang birahi pertama setelah beranak, akan semakin pendek selang beranak, dan sebaliknya. Hasil penelitian menunjukkan bahwa post partum estrus induk kambing Bligon yang dipelihara peternak di kelompok Purwo Manunggal adalah 63,16 hari dengan kisaran 30120 hari. Post partum estrus dipengaruhi salah satunya oleh faktor menyusui. Induk yang sedang menyusui akan mengalami unestrus dua sampai tiga kali lebih lama daripada yang tidak menyusui. Disamping itu, ketika sedang menyusui, aktivitas ovarium dan estrus mungkin tidak dapat diamati selama 2 atau 3 bulan lebih, terutama bila konsumsi energinya rendah (Bearden dan Fuquay, 1997). Post partum estrus tergolong normal antara 50-60 hari setelah beranak (Harjopranjoto, 1995).

Rerata post partum mating induk kambing Bligon yang dipelihara peternak di kelompok Purwo Manunggal berkisar antara 45-180 hari, dengan rerata 95 hari (Tabel 3). Rustadi (2008) dalam penelitiannya mendapatkan post partum mating pada induk kambing Bligon adalah 122 hari. Devendra dan Burns (1994) menyatakan bahwa kawin pertama setelah beranak baru timbul setelah kurang lebih tujuh bulan. Periode kawin setelah beranak dipengaruhi oleh timbulnya estrus pertama setelah beranak. Beberapa faktor yang mempengaruhi timbulnya estrus setelah beranak antara lain genetik, lingkungan, dan faktor metabolik (Hafez, 2000).

Interval kelahiran adalah periode antara dua kelahiran yang berurutan, terdiri atas periode perkawinan (periode dari beranak sampai konsepsi) dan periode bunting. Astuti (1983) menyatakan bahwa jarak antara waktu induk beranak sampai waktu induk dikawinkan kembali untuk pertama kali merupakan salah satu faktor yang mempengaruhi interval beranak. Periode perkawinan merupakan faktor penentu interval kelahiran yang penting. Hasil penelitian menunjukkan bahwa rerata interval kelahiran induk kambing Bligon adalah 8,53 bulan dengan kisaran 7-12 bulan. Basuki et al.
(1981) mendapatkan rerata interval kelahiran induk kambing Bligon adalah 7,8 bulan, sedangkan Tomaszewska et al. (1993) menyatakan bahwa interval kelahiran kambing Bligon yang dipelihara di pedesaan adalah 9-13,3 bulan. Hasil penelitian Prayitno (2003) memperoleh bahwa interval kelahiran induk kambing Bligon yang dipelihara oleh peternak di Kabupaten Bantul berkisar antara 10,310,7 bulan, sedangkan Rustadi (2008) mendapatkan bahwa interval kelahiran induk kambing Bligon di Desa Joton dan Gondangan, Kecamatan Jogonalan, Klaten adalah 8,33 dan 8,20 bulan. Dibandingkan dengan hasil-hasil penelitian ter-dahulu, maka interval kelahiran induk kambing Bligon pada penelitian ini masih tergolong normal, bahkan cenderung lebih baik. Lama periode per-kawinan tergantung pada seberapa cepat induk bunting lagi setelah beranak, yang pada gilirannya tergantung pada timbulnya kembali siklus birahi. Kondisi ini dipengaruhi oleh bangsa dan oleh beberapa faktor lingkungan (Devendra dan Burns, 1994).

\section{Pertambahan bobot badan harian (PBBH)}

Hasil PBBH kambing Bligon pada berbagai status ternak seperti tersaji pada Tabel 4. Hasil analisis statistik menunjukkan bahwa status ternak dan jenis kelamin tidak memberikan pengaruh yang signifikan terhadap PBBH kambing Bligon, walaupun demikian, terdapat kecenderungan bahwa kambing Bligon muda mempunyai $\mathrm{PBBH}$ yang relatif lebih tinggi dibandingkan dengan cempe maupun Bligon dewasa.

Hasil penelitian menunjukkan bahwa rerata PBBH cempe kambing Bligon pada penelitian ini sebesar $155 \mathrm{~g} / \mathrm{ekor} / \mathrm{hari}$. Beberapa hasil penelitian lain menunjukkan bahwa PBBH cempe Bligon jantan dan betina pada tipe kelahiran tunggal berturut-turut 101,5 dan 95,2 g/ekor/hari. Selanjutnya, pada tipe kelahiran kembar, PBBH cempe jantan adalah 88,7 g/ekor/hari sedangkan pada cempe betina adalah 64,8 g/ekor/hari (Medianto, 2009). Hasil penelitian lainnya juga menunjukkan hasil yang relatif sama, $\mathrm{PBBH}$ cempe kambing Bligon yang dipelihara oleh peternak di Kecamatan Kretek dan Piyungan, Kabupaten Bantul, DIY, berturutturut adalah 80,9 dan 85,7 g/ekor/hari (Prayitno, 2003) dan di Kabupaten Sleman sekitar 80,1 g/ekor/hari (Widi, 2002). Jika dibandingkan dengan hasil penelitian terdahulu, maka $\mathrm{PBBH}$ cempe Bligon pada penelitian ini relatif tinggi, hal ini kemungkinan disebabkan karena produksi susu induk cukup tinggi sehingga cempe cukup mendapatkan susu pada pertumbuhannya. Produksi susu induk yang tinggi disebabkan karena kualitas pakan yang diberikan telah memenuhi kebutuhan induk, 
Tabel 4. Rerata pertambahan bobot badan harian (PBBH) kambing Bligon pada berbagai status ternak (average dailey gain (ADG) of bligon goats at the different ages)

\begin{tabular}{|c|c|c|c|}
\hline Status ternak (animal ages) & $\begin{array}{c}\text { Bobot awal }(\mathrm{kg})(\text { initial } \\
\text { weight }(\mathrm{kg}))\end{array}$ & $\begin{array}{c}\text { Bobot akhir (kg) (final } \\
\text { weight (kg)) }\end{array}$ & ADG (kg/ekor/hari) \\
\hline \multicolumn{4}{|l|}{ Cempe $(k i d s)^{\mathrm{ns}}$} \\
\hline Jantan (male) & $4,75 \pm 2,17$ & $9,25 \pm 0,48$ & $0,15 \pm 0,06$ \\
\hline Betina (female) & $6,83 \pm 0,70$ & $11,50 \pm 1,15$ & $0,16 \pm 0,05$ \\
\hline \multicolumn{4}{|l|}{ Muda (young) ${ }^{\mathrm{ns}}$} \\
\hline Jantan (male) & $12,30 \pm 1,27$ & $20,90 \pm 1,27$ & $0,29 \pm 0,07$ \\
\hline Betina (female) & $14,00 \pm 0,86$ & $20,90 \pm 1,99$ & $0,26 \pm 0,08$ \\
\hline \multicolumn{4}{|l|}{ Dewasa $(a d u l t)^{\mathrm{ns}}$} \\
\hline Jantan (male) & $26,00 \pm 2,07$ & $34,20 \pm 4,02$ & $0,27 \pm 0,15$ \\
\hline Betina (female) & $31,23 \pm 2,04$ & $35,62 \pm 1,56$ & $0,15 \pm 0,09$ \\
\hline
\end{tabular}

hal ini dapat dilihat dari kenyataan bahwa peternak banyak memberikan ramban dengan berbagai jenis (21 macam ramban) tanaman liar pada ternaknya. Ketersediaan pakan yang melimpah ini diduga karena lokasi penelitian merupakan daerah yang berbatasan dengan hutan, sehingga peternak akan dengan mudah mendapatkan sumber pakan yang berkualitas tinggi. Keragaman dalam persediaan bahan pakan dan dalam pemberian pakan serta tatalaksana mempengaruhi efisiensi pengubahan zat makanan oleh induk (Devendra dan Burns, 1994), serta tinggi rendahnya $\mathrm{PBBH}$ pra-sapih cempe kambing Bligon sangat dipengaruhi oleh produksi susu induk (Manu, 2007; Anonimus, 2008).

Pada ternak muda (dara dan jantan muda), rerata $\mathrm{PBBH}$ hampir sama, meskipun terjadi kecenderungan bahwa jantan muda mempunyai PBBH yang lebih tinggi (290 g/ekor/hari) dibandingkan dengan jantan muda (260 g/ekor/hari). Utomo (2004) dalam penelitiannya menggunakan kambing Bligon betina berumur 5-6 bulan yang diberi pakan dasar rumput lapangan, daun nangka dan daun waru yang disubstitusi dengan daun pepaya tua $(0,25$, dan 50\%), memperoleh $\mathrm{PBBH}$ berturut-turut sebesar 8,6; 8,9; dan 13,3 g/ekor/hari. Hasil penelitian Tahuk et al. (2008) menunjukkan bahwa kambing Bligon jantan berumur sekitar 10-12 bulan yang digemukkan dengan aras protein yang berbeda (aras PK dalam ransum 9, 11, 13, dan 15\%), mampu menghasilkan PBBH yang tinggi, yaitu berturutturut 92, 106, 92, dan 114 g/ekor/hari. Tingginya PBBH kambing Bligon muda pada penelitian ini juga tidak terlepas dari kualitas dan kuantitas pakan yang diberikan. Umumnya peternak memberikan pakan dengan kualitas dan kuantitas yang cukup baik dan jenis pakan (rambanan) yang diberikan juga sangat bervariasi. Kenyataan bahwa lokasi penelitian adalah daerah pinggiran hutan, turut memperkuat dugaan ini, karena hutan merupakan sumber pakan utama dan berkualitas tinggi untuk ternak kambing, karena berbagai ramban dapat disediakan oleh hutan secara terus menerus. Selain itu, tingginya $\mathrm{PBBH}$ pada kambing muda dibandingkan dengan cempe maupun kambing dewasa, kemungkinan disebabkan karena pada umur-umur muda merupakan puncak pertumbuhan ternak, sehingga akan sangat efisien dalam memanfaatkan pakan menjadi produk daging. Dengan kualitas dan kuantitas pakan yang diberikan oleh peternak cukup baik, akan semakin meningkatkan laju pertumbuhan ternak.

Pada kambing Bligon dewasa (induk dan pejantan), walaupun secara statistik tidak menunjukkan perbedaan, terlihat bahwa kambing jantan mempunyai PBBH yang jauh lebih tinggi dibandingkan dengan induk. Rerata PBBH jantan adalah 270 g/ekor/hari, sedangkan pada induk adalah 150 g/ekor/hari. Perbedaan yang sangat tinggi ini, kemungkinan disebabkan karena indukinduk dalam kondisi menyusui, sehingga pakan yang dikonsumsi sebagian akan digunakan untuk memproduksi susu yang sangat dibutuhkan oleh cempe. Beberapa hasil penelitian terdahulu menunjukkan bahwa kambing Bligon jantan berumur 1,5 tahun yang digemukkan dengan pakan dasar rumput gajah dan jerami kacang yang disuplementasi dengan tepung gaplek, dedak halus dan ampas tahu (dengan perbandingan 35:35:30\%), mampu menghasilkan PBBH sebesar 73,2 g/ekor/hari, sedangkan yang hanya diberikan rumput gajah dan jerami kacang, $\mathrm{PBBH}$ yang dihasilkan sekitar 48,3 g/ekor/hari dengan konversi pakan 17,7 (Noor, 2008). Jika dibandingkan dengan hasil penelitian terdahulu, maka PBBH kambing Bligon dewasa pada penelitian ini lebih tinggi, hal ini kemungkinan disebabkan karena kualitas dan kuantitas pakan yang diberikan juga lebih baik.

\section{Kesimpulan}

Dari hasil penelitian awal ini dapat disimpulkan bahwa kinerja kambing Bligon yang dipelihara peternak adalah baik, ditinjau dari periode lama bunting, litter size, post partum estrus, post partum 
mating dan interval kelahiran. Pertambahan bobot badan harian kambing Bligon yang dipelihara oleh peternak cukup tinggi, baik pada cempe, kambing muda maupun kambing Bligon dewasa.

\section{Daftar Pustaka}

Aka, R. 2008. Produktivitas kambing Peranakan Etawah pada pola pemeliharaan sistem kandang kelompok dan kandang individu di Kecamatan Turi Kabupaten Sleman Propinsi DIY. Tesis. Sekolah Pascasarjana. Universitas Gadjah Mada. Yogyakarta.

Anonimus. 2008. Mengukur produksi ternak. Available at http://staffs.unud.ac.id. Acession date: June $30^{\text {th }}, 2009$.

Astuti, M. 1983. Parameter kambing dan domba di daerah dataran tinggi, Kecamatan Tretep, Kabupaten Temanggung. Dalam : M. Rangkuti, T. D. Sudjana, C. Knipscheer, P. Sitorus, A. Setiadi (Eds). Sheep and Goat in Indonesia. Prosiding Pertemuan Ilmiah Penelitian Ruminansia Kecil. Puslitbangnak, Badan Penelitian dan Pengembangan Pertanian. Departemen Pertanian, Bogor.

Astuti, M., A. Agus, I.G.S. Budisatria, L.M. Yusiati, dan M.U.M. Anggriani. 2007. Peta Potensi Plasma Nutfah Ternak Nasional. Edisi 1, Cetakan 1, Ardana Media, Yogyakarta.

Basuki, P., W. Hardjosubroto, dan N. Ngadiyono. 1981. Performance produksi dan reproduksi kambing Peranakan Etawah (PE) dan Bligon. Dalam : Domba dan Kambing di Indonesia. Proceeding Pertemuan Ilmiah Ruminansia Kecil. Pusat Penelitian dan Pengembangan Peternakan, Badan Penelitian dan Pengembangan Pertanian, Departemen Pertanian, Bogor.

Bearden, H.J. and J.W. Fuquay. 1997. Applied Animal Reproduction. $4^{\text {th }}$ ed., Prentice-Hall, Inc. USA.

Budisatria, I.G.S. 2000. Urea-molassess feeding in sheep : technical and socio-economic suitability in Central Java. M.Sc. Thesis. Wageningen University, The Netherlands. 79 pp.

Budisatria, I.G.S. 2006. Dynamics of small ruminant development in Central Java Indonesia. Thesis. Wageningen Agriculture University, Wageningen, The Netherlands. $144 \mathrm{pp}$.

Budisatria, I.G.S., H.M.J. Udo, C.H.M. Eilers, and A.J. Van der Zijpp. 2007. Dynamics of small ruminant production: A case study of Central Java, Indonesia. Outlook on Agriculture 36(2): 145-152.
Budisatria, I.G.S., A. Agus, L.M. Yusiati, Sumadi, dan Panjono. 2009. Studi tingkah laku dan produktivitas kambing Kejobong. Laporan Penelitian. Penelitian Kerjasama Internasional, Kegiatan World Class Research University (WCRU), Fakultas Peternakan, Universitas Gadjah Mada, Yogyakarta.

Devendra, C. dan M, Burns. 1994. Produksi Kambing di Daerah Tropis. Penerbit ITB. Bandung.

Doloksaribu, M., S. Elieser, F. Mahmilia, dan F.A. Pamungkas. 2005. Produktivitas kambing Kacang pada kondisi dikandangkan: 1. Bobot lahir, bobot sapih, jumlah anak sekelahiran dan daya hidup anak prasapih. Prosiding. Seminar Nasional Teknologi Peternakan dan Veteriner. Bogor.

Fitriani, Y. 2008. Konsumsi dan kecernaan nutrient induk kambing Bligon 8-14 minggu setelah beranak yang mendapat suplementasi sumber energi dan protein. Skripsi Sarjana Peternakan. Fakultas Peternakan, Universitas Gadjah Mada, Yogyakarta.

Hafez, E.S.E. 2000. Reproduction Cycle. In Hafez, E.S.E. (ed.) Reproductive in Farm Animals. $7^{\text {th }}$ ed. Lea and Febiger. Philadelphia.

Hardjopranjoto, H.S. 1995. Ilmu Kamajiran pada Ternak. Airlangga University Press. Surabaya.

Harjosubroto, W. 1994. Aplikasi Pemuliabiakan Ternak di Lapangan. PT. Grasindo, Jakarta.

Hardjosubroto, W., dan J.M. Astuti, 1993. Buku Pintar Peternakan. PT. Gramedia Widiasarana Indonesia, Jakarta.

Inounu, I. 1996. Keragaan produksi ternak domba prolifik. Disertasi. Pasca Sarjana Institut Pertanian Bogor, Bogor.

Jaenudeen, M.R. and E.S.E. Hafez. 1987. Reproductive Cycles: Cattle and Water Buffalo. In Hafez, E.S.E. (ed.) Reproductive in farm Animals. $5^{\text {th }}$ ed. Lea and Febiger, Philadelphia.

Kusnadi, U. 1980. Pelayanan perkebuntingan hasil kawin alam dan inseminasi buatan di daerah Pengalengan Lembang. Laporan Penelitian. Lembaga Penelitian, Bogor.

Loliwu, Y.A. 2002. Pengaruh pemberian hormon pregnant mare serum gonadotrophin dan human chorionic gonadotrophin terhadap beberapa sifat reproduksi kambing Kacang di Sulawesi Selatan. Tesis. Program Pasca Sarjana, Universitas Gadjah Mada, Yogyakarta.

Manu, A.E. 2007. Suplementasi pakan lokal urea gula air multi nutrien blok untuk meningkatkan kinerja induk bunting dan menyusui serta menekan kematian anak kambing Bligon 
yang digembalakan di Sabana Timor. Disertasi. Program Pasca Sarjana, Universitas Gadjah Mada, Yogyakarta.

Medianto, D. 2009. Pertumbuhan prasapih cempe kambing Bligon di Desa Joton dan Gondangan Kecamatan Jogonalan, Klaten. Skripsi Sarjana Peternakan. Fakultas Peternakan, Universitas Gadjah Mada, Yogyakarta.

Noor, A.R. 2008. Pertambahan bobot badan kambing Bligon jantan fase penggemukan dengan pakan tambahan dedak halus, tepung gaplek dan ampas tahu. Skripsi Sarjana Peternakan. Fakultas Peternakan, Universitas Gadjah Mada, Yogyakarta.

Prayitno, W. 2003. Kinerja induk kambing Bligon di Kecamatan Kretek dan Piyungan, Kabupaten Bantul, Daerah Istimewa Yogyakarta. Skripsi Sarjana Peternakan. Fakultas Peternakan, Universitas Gadjah Mada, Yogyakarta.

Rustadi, A.M. 2008. Kinerja induk kambing Bligon di Kecamatan Jogonalan Kabupaten Klaten Jawa Tengah. Skripsi Sarjana Peternakan.
Fakultas Peternakan, Universitas Gadjah Mada, Yoyakarta.

Sutimah. 2003. Kinerja induk kambing pada ketinggian lokasi yang berbeda di Kabupaten Kulon Progo Daerah Istimewa Yogyakarta. Skripsi. Fakultas Peternakan Universitas Gadjah Mada. Yogyakarta.

Tahuk, P.K., E. Baliarti, dan H. Hartadi. 2008. Kinerja kambing Bligon pada penggemukan dengan level protein pakan berbeda. Buletin Peternakan 32(2): 121-135.

Tomaszewska, M.W., I.M. Mastika, A. Djajanegara, S. Garner, dan T. Wiradarya. 1993. Reproduksi Kambing dan Domba di Indonesia. Sebelas Maret University, Solo.

Utomo, P. 2004. Kinerja produksi kambing Bligon yang diberi substitusi pakan daun pepaya (carica papaya). Skripsi Sarjana Peternakan. Fakultas Peternakan, Universitas Gadjah Mada, Yogyakarta.

Widi, T.S.M. 2002. Kinerja induk kambing dan domba pada tiga zona agro yang berbeda. Tesis. Program Pasca Sarjana, Universitas Gadjah Mada, Yogyakarta. 